\title{
The Climate Effect of Urbanization in A City of Developing Country: The Case Study of Ilorin, Kwara State, Nigeria \\ *Olanrewaju R.M. (Mrs)
}

\begin{abstract}
The impact of urbanization on climate with focus on minimum and maximum temperatures was examined for llorin city. The study period spanned through 1976-2005. Correlation and regression statistics were employed to investigate relationship and trend was also identified using ten years moving average. The result of the analyses show maximum temperature having a strong positive relationship significant at 0.01 confidence level while mild positive relationship occurred between minimum temperature and population growth. Population growth account for $67.5 \%$ and $74 \%$ variability observed in minimum and maximum temperature and the trends show a general rise in all the variables.
\end{abstract}

\section{Introduction}

U loxpanization is defined as the metropolitan areas and the growth in the proportion of its population. The process of urbanization involves human activities that tend to alter chemical composition of the atmosphere, the thermal and hydrological properties of the earth's surface as well as the aerodynamic roughness parameters. For instance, marshes are drained, local vegetation is removed and soil is turned as natural surfaces are replaced by more impervious surfaces such as pavements, tarred roads and building roofs. Other human activities that encourage generation of green house gases such as building industries and increasing the number of automobiles are taking place in urban areas. These bring about increase in urban temperature compared with its rural areas the phenomenon termed "Urban Heat Island" (UHI). To corroborate this, Zhou and Robert (2004) attributed the climatic change experienced in urban areas to UHI created by land use changes from urbanization. High temperature creates considerable discomfort and stress on man's level of performance and hence on his economic activities.

According to the United Nations (UN) definition, urbanized area in Africa represents any locality with 20,000 or more inhabitants. Based on this, Ilorin has attained the status of an urbanized area since early $20^{\text {th }}$ century (Oyegun, 1983). As a matter of fact the population of Ilorin doubled its size within 30 years of 1976-2005 (see appendix 1). Thus there is a need to examine the impact such growth in the proportion of Ilorin population has on its climate for effective mitigation or adaptation towards a buoyant economy in Ilorin city.

\footnotetext{
* Department of Geography University Of Ilorin, Nigeria
}

\section{Urbanization and Climate}

Increase in population brings about increase in size of urban area. World Urbanization Prospects 2005 annual report described $20^{\text {th }}$ century as witnessing the rapid urbanization of the world's population as the global proportion of the urban population rose dramatically from $13 \%$ (220 million) in 1900 to $49 \%$ ( 3.2 billion) in 2005 . This has resulted in the shifting of residential area outward a process called suburbanization. Various authors at different times have emerged with different terminology to describe the formation of such new points of concentration outside downtown. For instance, Garraeu (1991) referred to it as exurbia, edge city, Batten (1995) called it network city while Dear (2000) described it as postmodern city. According to UN-Habitat 2006 annual report, majority of people worldwide will be living in towns or cities for the first time by the middle of 2007 (Urban Millennium) and by estimation $93 \%$ of urban growth will occur in Asia and Africa.

The negative influence of the rapid urban growth on climate is a concern for many researchers. Urban microclimate is the climate develop over a city and modified by variation in aspect, shape and form of the ground, soil moisture and surface vegetation (Oke, 1987).

Goudie (1997) stressed that the most pronounced and locally far reaching effects of man's activities on microclimate have been in cities. For instance Getis et al (1998) discovered that smog is formed faster in cities because of the hot weather. Almost every city in the world is between $1-4^{0} \mathrm{C}$ hotter than its surrounding areas. For every degree rise in temperature electricity generation rises by $2 \%$ - $4 \%$ and smog production increases by $4 \%$ $10 \%$. Zhou and Robert (2004) generally find out that human induced changes in landuse 
such as urbanization among others affect both local and regional climate and even large scale atmosphere circulations.

\section{The study area}

Ilorin the study area located approximately on lat $8^{0} 30^{\prime} \mathrm{N}$ of the equator and long $4^{0} 35^{\prime} \mathrm{E}$ of the Greenwich Meridian has an area of about $100 \mathrm{~km}^{2}$. Ilorin experiences a tropical wet and dry climate with mean annual rainfall of $1,200 \mathrm{~mm}$ (Olaniran, 2002). Its temperature varies between $25^{\circ} \mathrm{C}$ to $30^{\circ} \mathrm{C}$ in March which marks the hottest month.

Ilorin has been described as one of the fastest growing urban centres in Nigeria, has a population of 40,990 in 1952, 208,546 in 1984 (Oyegun, 1985). By 1991 census the city's population has increased to 552,088 and 780,771 in year 2005. Aderamo (2002) highlighted some of the reasons for such growth to include the centrality of Ilorin city, the creation of states in 1967 and 1976, the rapid growth of commerce, industrialization and other social aspects.

\section{Material and methods Types and sources of data}

Population and temperature data were utilized in this study. Population data (population and growth rate projected) were collected from the National Population Commission (NPC) Ilorin and temperatures (minimum and maximum) data were obtained from Nigeria Meteorological Agency (NIMET) Ilorin Airport. Both data were collected for thirty years period spanning between 1976-2005.0

\section{Data Analysis}

Trend was identified using 10 years moving average. Correlation and regression methods were used to investigate relationship between population and temperatures.

\section{Results and Discussion}

\section{Population Growth in Ilorin (1976-2005)}

Figure 2 reflects the population growth rate of Ilorin the study area from 1976-2005. The inhabitant grew from 367,930 in 1975 to 780,771 in year 2005 . Ilorin population more than doubled its size within 30 years with the growth rate range of approximately $2.5 \%$ $2.9 \%$. The resultant effect of such growth led to rapid urbanization within the study period and its implications on the micro climate of Ilorin cannot be overemphasized.

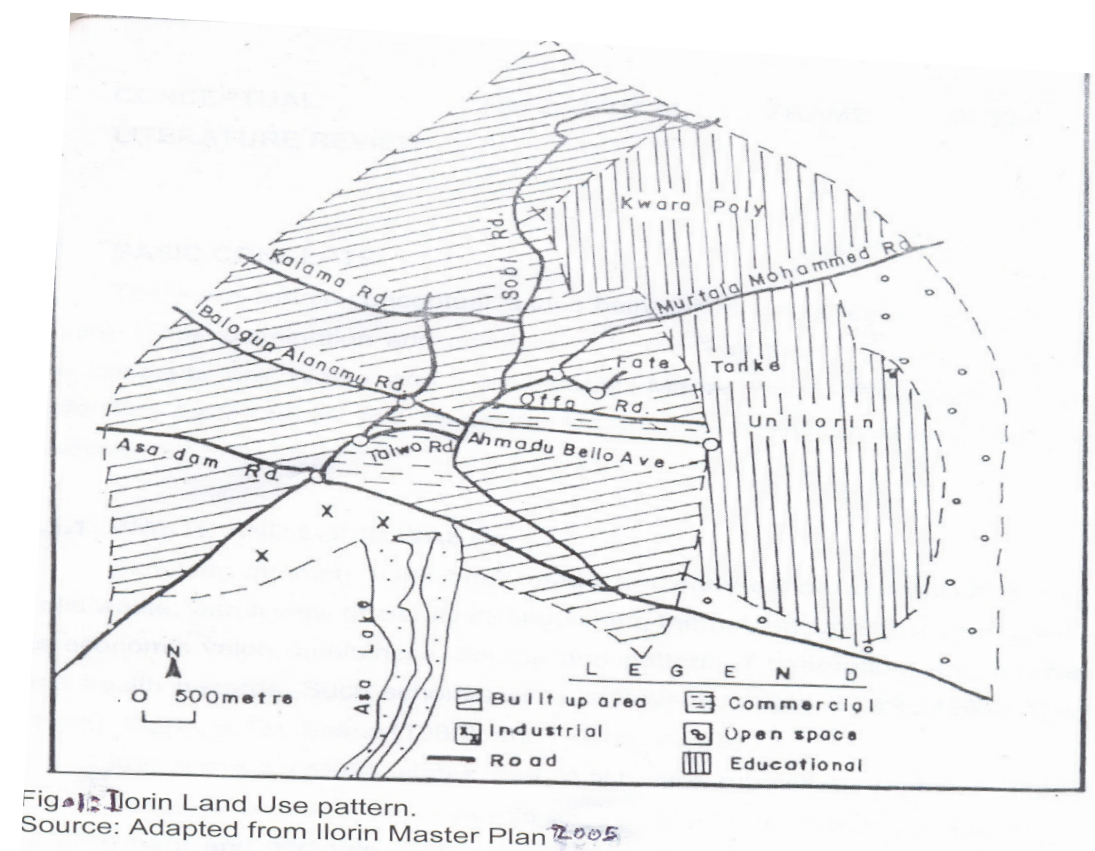




\section{Temperature trends in Ilorin (1976-2005)}

The trends of the ten year moving average for minimum, maximum and averaged temperature is discussed in this section.The trend for minimum temperature is shown in figure 3a. Fluctuations exist but the general trend shows a rise which becomes steady during the last decade.

The pattern of trend observed in maximum temperature is almost similar with that of minimum temperature (Fig. 3b). The rise in minimum temperature is steadier. The rise in maximum temperature is noted between 1980-1990 but thereafter a short period of a slight decline occurred between 1990-1992. The steady rise re-established between 19932005.

The average temperature trend of Ilorin for the period 1976-2005 is shown in figure 3c. A sharp decline was noticed in 1986, however the last decade 1995-2005 also witnessed a steady rise.

The findings above show that the variables (population growth and temperature) share one characteristics of a rise within the study period. However to be more precise about the strength of the relationship between variables correlation and regression analysis were carried out and the results discussed.

\section{Results of correlation analysis}

The result of correlation carried out is presented in Table 1. Positive relationship exists between population growth and temperatures but with variation in strength.
The implication is that as population rises temperature also rises. While weak positive relationship exists between population and minimum temperature and between averaged temperatures. Maximum temperature exhibit a stronger positive relationship of 0.48 which is significant at 0.01 confidence level. This finding has established the fact Ilorin city is becoming warmer and that the climate of the city is being modified by the rapid urbanization going on in the city.

. Table II reflects population growth as a significant determinant of minimum, maximum and average temperatures in Ilorin metropolis. The coefficients 0.543 for minimum temperature, 0.426 for maximum temperature and 0.654 for average temperature indicate that $10 \%$ change in population will lead to $5 \%$ increase in minimum temperature, $4 \%$ in maximum temperature and $6 \%$ increase in average temperature. Population growth accounted for $67 \%, 74 \%$ and $54 \%$ variability in minimum, maximum and average temperature respectively (table II).

\section{Conclusion}

Ilorin city is becoming warmer consequent of rapid urbanization taking place in the area, the resultant effects of this on man's health and hence on his economy can be fatal if not curbed. Further research efforts should be geared towards finding ways of mitigating the negative effects of urbanization on climate.

Fig. 2 POPULATION OF ILORIN (1976-2005)

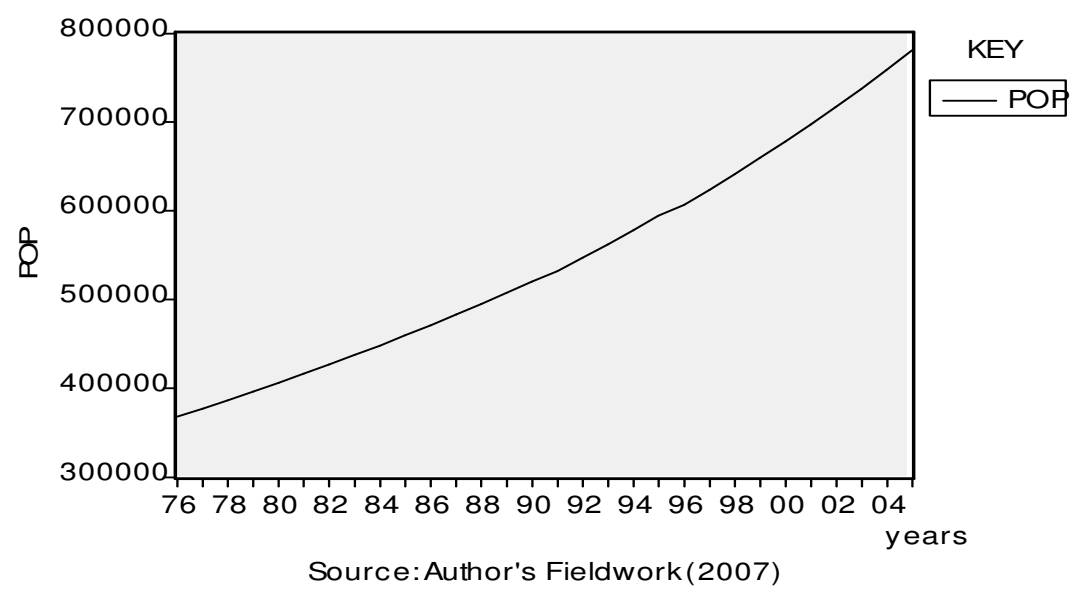




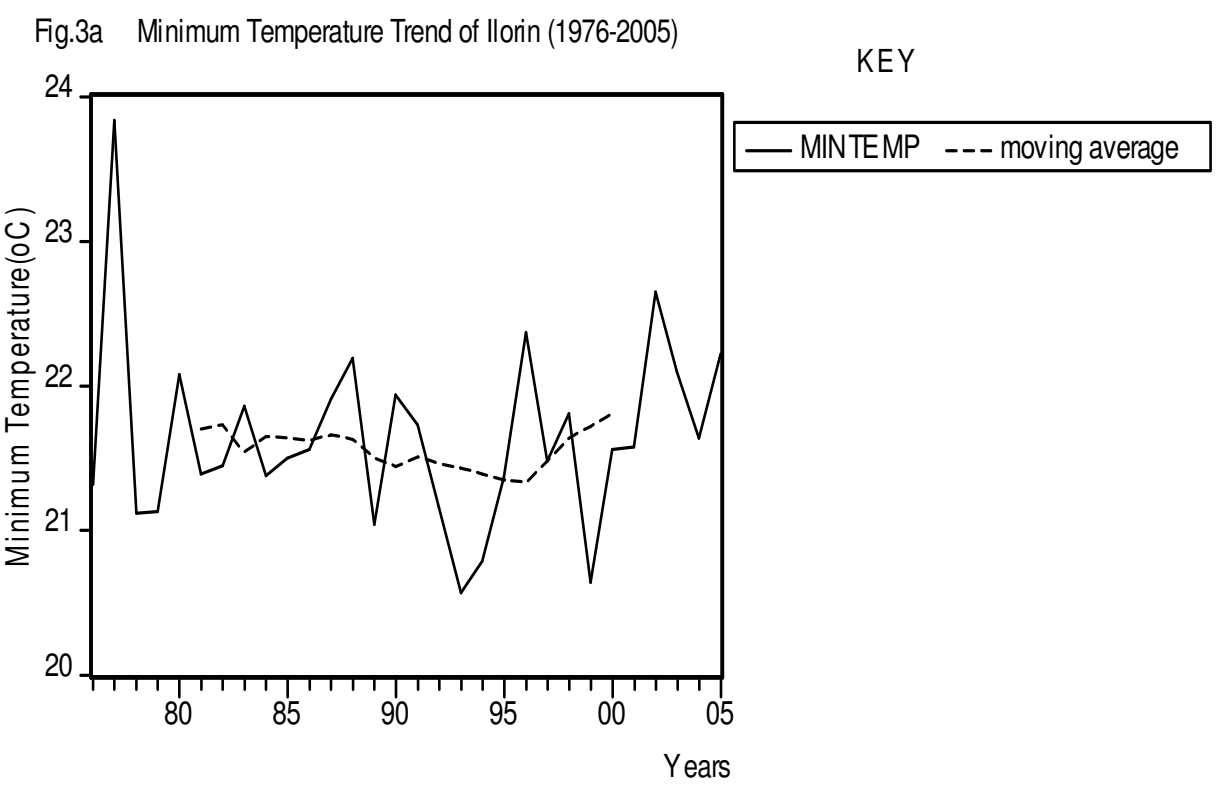

Source: Author's Fieldwork (2007)

Fig.3b Maximum Temperature Trend of Ilorin (1976-2005)

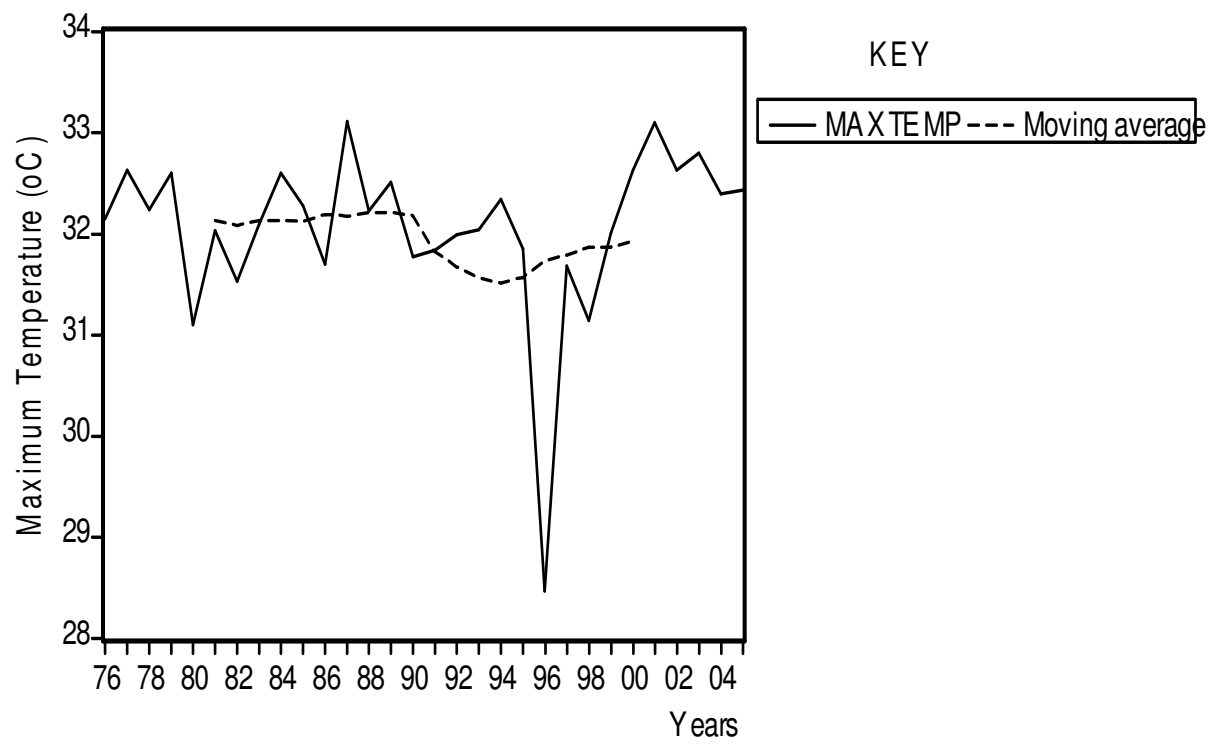

Source: Author's Computation 
Fig.3c Average Temperature Trend of Ilorin (1976-2005)

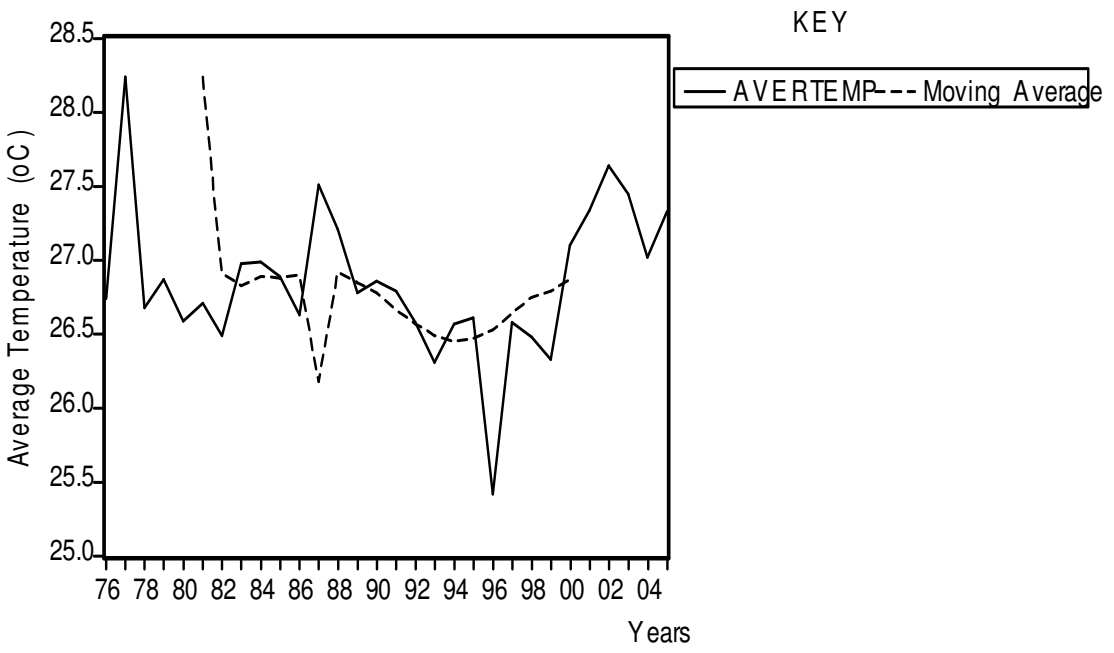

Source: Author's Fieldwork (2007)

Table 1: Results of correlation between population and temperature in Ilorin (1976-2005)

\begin{tabular}{|l|l|l|}
\hline Climatic parameter $\left({ }^{0} \mathrm{C}\right)$ & $\begin{array}{l}\text { Correlation } \\
\text { coefficient }\end{array}$ & Remarks \\
\hline Minimum temperature & 0.23 & Mild positive \\
Maximum temperature & $* * 0.43$ & Strong positive \\
Average temperature & 0.25 & Mild positive \\
\hline
\end{tabular}

** significant at 0.01 level

Source: Author's computation, 2007

Table II: Result of the Regression Analysis (t- statistic value)

\begin{tabular}{|l|l|l|l|}
\hline $\begin{array}{l}\text { Independent } \\
\text { variable }\end{array}$ & $\begin{array}{l}\text { Minimum } \\
\text { temperature }\end{array}$ & $\begin{array}{l}\text { Maximum } \\
\text { temperature }\end{array}$ & $\begin{array}{l}\text { Average } \\
\text { temperature }\end{array}$ \\
\hline $\begin{array}{l}\text { Population } \\
\text { growth }\end{array}$ & $\begin{array}{l}23.637 \\
(14.788)\end{array}$ & $\begin{array}{l}26.734 \\
(14.225)\end{array}$ & $\begin{array}{l}25.186 \\
(20.115)\end{array}$ \\
& 0.543 & 0.426 & 0.654 \\
$\mathrm{R}^{2}$ & $(2.435)$ & $(2.843)$ & $(2.325)$ \\
$\mathrm{R}^{-2}$ & 0.675 & 0.743 & 0.542 \\
$\mathrm{~F}$ & 0.643 & 0.722 & 0.531 \\
$\mathrm{D} . \mathrm{W}$ & 6.436 & 8.081 & 5.432 \\
\hline
\end{tabular}

Source: Author's computation 2007 


\section{References}

Aderamo, A.J. (2004), "Transport in the Structure and Growth of a Traditional City". Geo-studies Forum: An International Journal of Environmental and Policy Issues, Vol. 2, Pp. 145-158. Dept. of Geog. University of Ilorin.

Ayoade, J.O. (2004), Introduction to Climatology for the Tropics .John Wiley Press.

Batten, D.F. (1995), "Network Cities: Creative Urban Agglomerations for the $21^{\text {st }}$ century". Urban Studies, 32, 361-378.

Dear, M.J. (2000), Postmodern Urban Condition. Oxford: Blackwell.

Eric, H. (2005), The Age of the Revolution: 1789-1848 . Chap. II.

Garreau, J. (1991), Edge City: Life on the new frontier. New York: Anchor Books.

Getis, A., Getis, A. and Fellman, J.D. (1998), Introduction to Geography. WCB Mc Graw Hill.

Goudie, A. (1997), The Human Impact Reader: Readings and Case Studies. Blackwell Publishers.

Oke, J.R. (1987), Boundary Layer Climate, $2^{\text {nd }}$ Edition, Routledge.

Olaniran, O.J. (2002), "Rainfall Anomalies in Nigeria: The Contemporary Understanding The FiftyFifth Inaugural Lecture of the University of Ilorin.

Oyegun, R.O. (1983), Water Resources in Kwara State, Matanmi and Sons Printing and Publishing Co. Ltd., Ilorin.

Oyegun, R.O. (1985), “The Use and Waste Water in a Third War World City”,Geojournal, Reidel Publishing Company, 10.2, 205-210.

Revision of the United Nations (UN) World Urbanisation Prospects 2006 Annual Report.

UN-HABITAT 2006 Annual Report.

World Bank 2005: Urbanization Worldwide INDIS (PDF file).

Zhou, L. and Robert, D. (2004), "Research News and Publications", Greenhouse Bulletin, No. 125.

htt://en.wikipedia org/wiki/urbanization

http://www.arch.hku.hk/cmhui/teach/65156-7f.htm. 